\title{
The Ability of Prospective Elementary School Teachers to Develop Student Worksheets on Context-Based Science Learning
}

\author{
G Hamdu ${ }^{\bowtie 1}$ and A Yulianto 2 \\ 1,2 Prodi PGSD Tasikmalaya, Universitas Pendidikan Indonesia, Bandung, Indonesia \\ $\triangle$ ghullamh2012@upi.edu
}

\begin{abstract}
The use of student worksheets (LKS, Lembar Kerja Siswa) can assist teachers in developing and implementing the learning process in the classroom. Prospective elementary school teachers need to be equipped with the ability to develop innovative LKS so that they can be used for learning process. This study aims to identify the ability of prospective elementary school teachers in developing worksheets on context-based science learning through debriefing programs. The stages of the debriefing program consist of: giving initial assignments and understanding, implementing design, and workshops, reviewing/reflecting the design results (group discussions and presentations), and making improvement. This debriefing program was attended by 80 college students from preservice elementary school teacher level four at one university in the West Java region, Indonesia. LKS products before and after debriefing are described based on several aspects and then analyzed to determine the effect of the debriefing program on improving college students' ability in developing LKS. The results show that the debriefing program can lead to the college students' ability to develop LKS on context-based science learning. The improved ability is related to: clarity in the use of written language, concept stages, context use, showing the authenticity of the task and the use of learning media.
\end{abstract}

Keywords: Debriefing program, context-based science, student worksheet.

How to Cite: Hamdu, G., \& Yulianto, A. (2018). The Ability of Prospective Elementary School Teachers to Develop Student Worksheets on Context-Based Science Learning. Mimbar Sekolah Dasar, 5(3), 155-161. doi:http://dx.doi.org/10.17509/mimbar-sd.v5i3.14503.

INTRODUCTION Learning is done by stimulating students to have access to a variety of sources relevant to the issues examined, which facilitate understanding and ensure the completion of the task against (Gorghiu, Drăghicescu, Cristea, Petrescu, \& Gorghiu, 2015). A task that will be developed by the teacher with the orientation to increase the intellectual students in thought processes (Carless, 2004; Kang, 2017). Draft task can stimulate students to give active responses regarding the problems of authenticity at the time of learning. Deeply thinking skills and the ability to use motor students' complete problems occurred (Herrington \& Herrington, 2006). If learning is constructed with a task, then the students aren't only trying to understand the concept of it, but also the underlying mechanism of duties (Harden, Crosby, Davis, Howie, \& Struthers, 2000). This means that the concept was acquired gradually through the learning process.

Problem solving was guided by LKS as a part of the learning process. The implementation of the learning stage was rationally designed with the appropriate 
Ghullam Hamdu \& Ade Yulianto, The Ability of Prospective Elementary School Teachers...

method. The context used could be used by various media with significant environmental involvement. The analysis of context-based LKS development was then described through the learning steps by integrating some rational and appropriate concepts (Hamdu \& Sopandi, 2018). It has already known that the teachers are required to complete their duties and their roles are no longer as informants of the knowledge, but their roles should be as a motivator in the process of teaching and learning so that students can construct their own knowledge through various activities in the learning activities. Through the use of the student worksheets in the learning process, the students are expected to learn a subject matter independently (Yaden, 2017).

But in Indonesia, often in the form of worksheets guidelines to facilitate students learn to solve those problems is not appropriate (Harden et al., 2000; Murtikusuma, 2017; Rahayu, Muhsetyo, \& Rahardjo, 2016). Learning guidelines developed by teachers are often misinterpreted as a question with a view to unearth the knowledge students not how students experience the acquisition of knowledge. Training of profesonalism teachers with regard to the development of the employment guidelines by making the task of the student or any LKS is rarely done (Hamdu \& Sopandi, 2018).

In the legislation of the Republic of Indonesia No. 14-year 2005, The job of the teacher is the work of professionals. The teacher has professional position to provide expert service and this demands academic, pedagogical, social, and professional skills requirements. The result of teacher competence test in 2015 showed low teacher pedagogical competence and considered that Teacher Training Colleges (LPTK, Lembaga Pendidikan Tenaga Kependidikan) as the most responsible institution. Teachers are products of LPTK, so this institution should be more responsible for such condition (Caraka \& Ika, 2016). Therefore, the development of teacher education to produce professional teachers should be prepared when taking formal education teacher training in LPTK (Hamdu \& Sopandi, 2018). Therefore required a debriefing program can prepare prospective teachers to develop learning are good. This research tries to implement a debriefing program has been developed by researchers and has been published by focusing on the LKS analysis has been developed by the student's college.

\section{METHODS}

\section{Participant}

As many as 82 students in Preservice Elementary School Teacher Education Program semester 7 which consist of 2 classes (Science 1 and Science 2) as a subject of research. Each grade is divided into 8 groups and each group acquiring study materials science that will be developed into the science-based learning design in the context of the 
thematic-integrated with other subjects. Although in one group I get one study cemeteries science are the same, but each student's college develops the draft must produce different learning. LKS is one part of the learning that will be developed by the student's college.

\section{Design of Debriefing Program}

Design of debriefing program adopted phase have been developed by Hamdu and Sopandi (2018). The design of the implementation phases of the programs illustrated in Figure 1.

DEBRIEFING STAGE: FACE TO FACE (SECTION 1 AND 2)

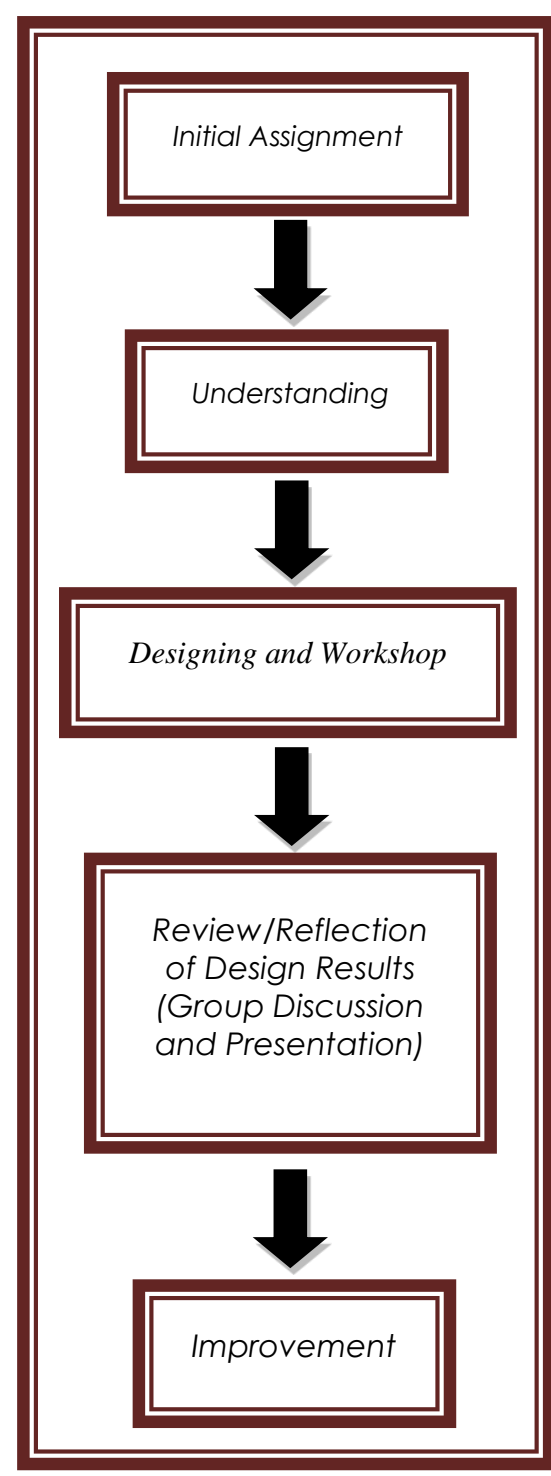

DEBRIEFING STAGE: FIELD IMPLEMENTATION (SECTION 3)

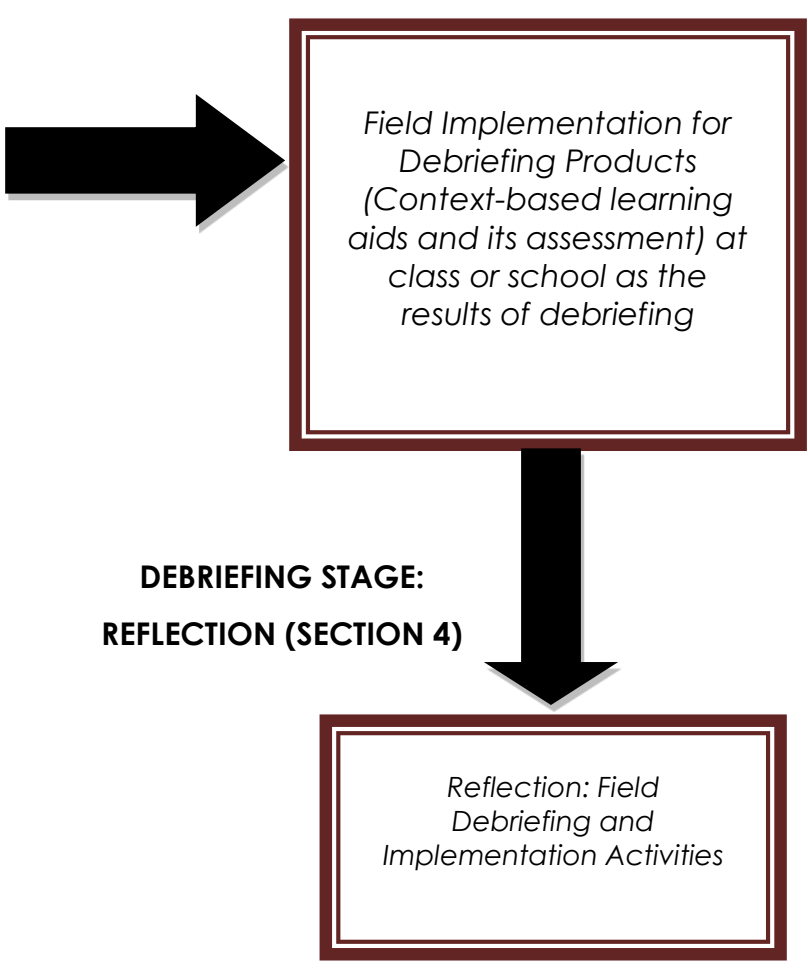

Figure 1. Phases of debriefing program 


\section{Implementation of Debriefing Program}

Stages of the debriefing program do with four parts. The first and second section deals with in person meetings by discussing conceptual and product development that consists of an analysis of the curriculum, teaching material analysis by using concept maps, development of LKS and learning media, development stages, context-based learning, problem-based HOTS (Higher-Order Thinking Order Thinking Skills), alternative assessment, and rubrics. The third part is product implementation learning device, and the fourth part does a reflection towards the implementation of the program as a whole. The study in this article specifically discusses the results obtained from students' college in developing the LKS. Development of LKS made after analyzing the curriculum and develop a concept map to analyzing the concept of science who later carried out a thematic-integrated learning. In person phases (part 1 and part 2) are performed with a five to six hours to produce.

\section{Analisys of Data}

Data obtained from the results of students college in developing LKS before and after implementing the debriefing program. LKS generated by the student college before debriefing is considered the first capabilities has been owned by the student college in the previous lecture while the results after a debriefing is considered the ability of the student's college after following debriefing. The assessment does by giving a score based on the aspect. Data processed and discussed with improved earnings results and score-score in every aspect. As for the aspect of the development is LKS in a score related to: clarity in the use of written language, concept stages, context use, showing the authenticity of the task and the use of learning media.

\section{RESULTS AND DISCUSSION}

Granting score on the results of the LKS created by the student college is done before and after phases of debriefing face-to-face. Figure 2 describes the ability of the student in developing the students worksheet with the aspects analysed with regard to: clarity in the use of written language, concept stages, context use, showing the authenticity of the task and the use of learning media.

The ability of the student college through the initial assessment of the results of the initial assignment the students cumulatively has not shown a good ability in developing LKS. The quality of the LKS content there are still many shortcomings. These results show that the gains could be LKS development concept in a lecture not previously touched on the quality of the LKS. LKS development needs that must exist on the pretext that the teacher is obliged to let students be active by using the LKS. Meanwhile, with regard to the content and mechanisms of LKS development negligible. LKS is just being a regular field assignment with such questions for the purpose of evaluating the ability of students. 


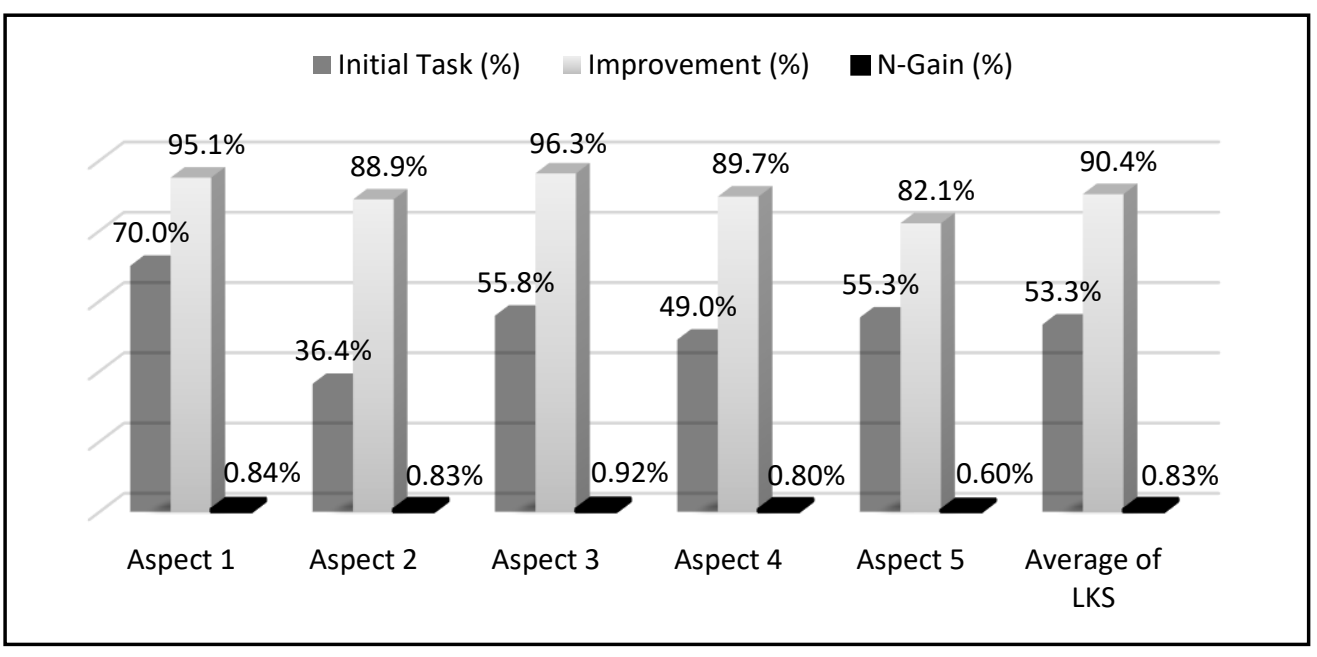

Figure 2. The average student college results in developing LKS

After making a debriefing program, the results of students college in developing of LKS show an improvement (see Table 1). Implementation of debriefing program has been given the opportunity to students college to undertake activities to understand through faqs, improvement products that have been made through product design development activities gradually, workshop development products and discuss any product results of student college in a small group or class. Improvement of product has been through the various considerations the results of discussions. So it is very reasonable if this debriefing program stages can improve the quality product being better than ever.

Table 1. Result scoring of LKS development

\begin{tabular}{|c|c|c|c|c|c|c|c|c|}
\hline \multirow[t]{2}{*}{ Aspect of Development of LKS } & \multicolumn{4}{|c|}{$\begin{array}{l}\text { \% Aspect Scoring } \\
\text { (Initial assignment) }\end{array}$} & \multicolumn{4}{|c|}{$\begin{array}{l}\text { \% Aspect Scoring } \\
\text { (Increase) }\end{array}$} \\
\hline & 1 & 2 & 3 & 4 & 1 & 2 & 3 & 4 \\
\hline $\begin{array}{l}\text { 1. Clarity in the use of written } \\
\text { language }\end{array}$ & 4,0 & 29,3 & 49,2 & 17,5 & 1,2 & 3,7 & 8,5 & 86,6 \\
\hline 2. Concept stages & 25,2 & 72,4 & 2,4 & 0,00 & 2,0 & 5,7 & 16,7 & 75,6 \\
\hline 3. Context use & 34,7 & 62,8 & 2,5 & & 1,5 & 8,3 & 90,2 & \\
\hline $\begin{array}{l}\text { 4. Showing the authenticity of the } \\
\text { task }\end{array}$ & 26,5 & 50,5 & 23,0 & 0,00 & 2,4 & 8,5 & 16,9 & 72,2 \\
\hline 5. The use of learning media & Yes & No & & & Yes & No & & \\
\hline Total & 41,2 & 58,8 & & & 82,1 & 17,9 & & \\
\hline
\end{tabular}

Note: The number of students participating in the debriefing was 82 people.

Rubric Scoring:

$1 \rightarrow<49 \%$ of the contents of the worksheets that have been made show compliance with aspects

$2 \rightarrow 50 \%-69 \%$ of the contents of the worksheets that have been made show compliance with aspects

$3 \rightarrow 70 \%-84 \%$ of the contents of the worksheets that have been made show compliance with aspects 
Ghullam Hamdu \& Ade Yulianto, The Ability of Prospective Elementary School Teachers...

$4 \rightarrow 85 \%-100 \%$ of the contents of the worksheets that have been made show compliance with aspects

$3 \rightarrow$ clearly written according to aspects

$2 \rightarrow$ implicitly according to aspects

$1 \rightarrow$ Nothing / unwritten / implied

There or not according to aspects: Yes $\rightarrow 1$, No $\rightarrow 0$

Results before implementing debriefing acquisition the accumulated scoring 3 and 4 to 1 aspect is more than $50 \%$ (range scoring 1 - 4). This result may indicate that a several of students college on such data have largely understood that developers of LKS need to pay attention to the use of language. LKS for student in the elementary school need to use the phrase or word which is clear to not give rise to a lot of interpretation. But the earnings are good enough for this aspect of 1 not shown in other aspects. Aspect 2 and aspect 4 gains accumulated scoring 1 and 2 more than $50 \%$, the acquisition of more at scoring 2 and there is not several of student college have a maximum scoring (4). The description LKS created by the student college has not shown how the concept of systematic acquisition stages and examples of tasks that developed has not shown the actual situation on the condition.

Development of the LKS tends to give a number of questions as well as a written test to confirm the understanding of the students against a particular concept. Stages of the derivation of the concept of using the actual situation is not clearly visible because the students college gave more focus to understanding the concept. This result is directly proportional to how students college uses learning media context and to help the process of understanding that have been described in the LKS. Comulatively in the context of the use of the LKS most students college did not show clearly. Only a few students college describe the context (2.5\%). The specified context is a learning situation with students, the experience is linked to the previous understanding of the environmental situation, and the classes that support the completion of the task.

After doing the debriefing program, every aspect of the program showed an increase with the acquisition of maximum scoring. Most of the students college have provided a good overview in developing LKS with considering aspect: clarity in the use of written language, concept stages, use context, showing the authenticity of the task and the use of learning media. In line with other studies, debriefing programs can improve students' knowledge and abilities and provide good learning experiences (Brown, Wong, \& Ahmed, 2018; Mavin, Kikkawa, \& Billett, 2018).

\section{CONCLUSION}

The process of teaching and learning by using science-based learning LKS in context in elementary school can help students to make the learning activity. LKS as a guide student learning should be 
developed by the teacher are good. At least the good Sheet, programme on: clarity in the use of written language, concept stages, use context, showing the authenticity of the task and the use of learning media. Students college as prospective teachers need to improve competence in designing learning activities in the form of LKS through a planned debriefing program.

\section{REFERENCES}

Brown, D. K., Wong, A. H., \& Ahmed, R. A. (2018). Evaluation of simulation debriefing methods with interprofessional learning. Journal of Interprofessional Care, 1-3. doi:10.1080/13561820.2018.1500451

Caraka, P. B., \& Ika, M. (2016). Strategi Lptk Dalam Pengembangan Kompetensi Pedagogik Calon Guru. Jurnal Pendidikan (Teori dan Praktik), 1 (02), 96-106.

Carless, D. (2004). Issues in teachers' reinterpretation of a task-based innovation in primary schools. Tesol Quarterly, 38(4), 639-662.

Gorghiu, G., Drăghicescu, L. M., Cristea, S., Petrescu, A.-M., \& Gorghiu, L. M. (2015). Problem-based Learning-An Efficient Learning Strategy in the Science Lessons Context. Procediasocial and behavioral sciences, 191, 1865-1870.

Hamdu, G., \& Sopandi, W. (2018). Debriefing Program for Prospective Elementary School Teachers in Developing Learning Aids. International Journal of Learning, Teaching and Educational Research, $17(6)$.

Harden, R., Crosby, J., Davis, M., Howie, P., \& Struthers, A. (2000). Task-based learning: the answer to integration and problem-based learning in the clinical years. Medical EducationOxford, 34 (5), 391-397.

Herrington, J. A., \& Herrington, A. J. (2006). Authentic conditions for authentic assessment: Aligning task and assessment.

Kang, H. (2017). Preservice teachers' learning to plan intellectually challenging tasks. Journal of Teacher Education, 68(1), 55-68.

Mavin, T. J., Kikkawa, Y., \& Billett, S. (2018). Key contributing factors to learning through debriefings: commercial aviation pilots' perspectives. International Journal of Training Research, 16(2), 122-144. doi:10.1080/14480220.2018.1501906

Murtikusuma, R. P. (2017). Pengembangan lembar kerja siswa matematika model problem-based learning untuk smk perkebunan bertemakan kopi dan kakao. Pancaran Pendidikan, 5(4), 5160.

Rahayu, A., Muhsetyo, G., \& Rahardjo, S. (2016). Pengembangan Lks Bercirikan Problem Based Learning untuk Siswa SMP Ar-rohmah Malang Kelas VII. Jurnal Pendidikan: Teori, Penelitian, dan Pengembangan, 1 (6), 1056-1066.

Yaden, Z. (2017). A Development of Students' Worksheet Based on Contextual Teaching and Learning. International Journal of Learning, Teaching and Educational Research, 16(6). 